\title{
PERTUMBUHAN DAN PRODUKSI 2 VARIETAS KEDELAI HITAM (Glycine soja) TERHADAP PEMBERIAN BEBERAPA JENIS PUPUK ORGANIK (BOKASHI) DI LAHAN KERING
}

\section{(Growth and Production of 2 Varieties of Black Soybean (Glycine soja) against the Provision of Several Types of Organic Fertilizers (Bokashi) in Dry Land)}

\author{
${ }^{1)}$ Muhammad Rizal, ${ }^{2)}$ St. Subaedah, ${ }^{2)}$ Aminah Muchdar \\ ${ }^{1)}$ Program Studi Agroekoteknologi, Program Pascasarjana UMI \\ 2)Program Studi Agroteknologi Fakultas Pertanian UMI \\ ${ }^{1)}$ Email izalmr479@ gmail.com \\ ${ }^{2}$ Email st.subaedah@umi.ac.id \\ ${ }^{2)}$ Email aminah.muchdar@umi.ac.id
}

\begin{abstract}
This research aims, 1). To assess the growth and production of two black soybean varieties. 2). To examine the effect of using organic fertilizer on the growth and production of black soybean. 3). To examine the interaction between various types of organic fertilizers and varieties on the growth and production of black soybeans.This research was conducted at the practice site of the Gowa Agricultural Development Polytechnic (Polbangtan), located at Romanglompoa Village, Bontomarannu, Gowa District. This research was conducted from July to December 2018. Data obtained from observations were analysed statistically (Analysis of variance with the F test) in accordance with the design used. In this study the experiments were analysed using the Split Plot Design. If the variance shows that $F$ count is real or very real, then the data analysis is continued with the test using the Least Significant Difference test (LSD). The results showed that Detam-3 varieties had a significantly different effect with Detam-4 on the growth and production of black soybean plants, mixed organic fertilizer (bokashi manure, rice straw, and rice husk) showed the best effect on the growth and production of black soybean, and there is no interaction between the type of organic fertilizer and soybean varieties on the growth and production of black soybean. It is recommended to use Detam-3 black soybean varieties accompanied by the use of bokashi organic fertilizer made from rice straw as part of a zero-waste farming system to support optimum production.
\end{abstract}

Keywords : Bokashi; Black Soybean; dry land

\section{PENDAHULUAN}

Kedelai merupakan sumber protein nabati paling populer bagi masyarakat Indonesia pada umumnya. Konsumsi utamanya dalam bentuk tempe dan tahu yang merupakan lauk pauk utama bagi masyarakat Indonesia. Bentuk lain produk kedelai adalah kecap, tauco, dan susu kedelai. Produk ini dikonsumsi oleh sebagian besar masyarakat Indonesia, rata-rata kebutuhan kedelai per tahun adalah 2,2 juta ton. Ironisnya pemenuhan kebutuhan kedelai sebanyak 1,5 juta ton $(67,99 \%)$ harus diimpor dari luar negeri. Hal ini terjadi karena produksi dalam negeri tidak mampu mencukupi permintaan produsen tempe dan tahu. Indonesia merupakan negara produsen tempe terbesar di dunia dan menjadi pasar kedelai terbesar di Asia. Berdasarkan data 
SUSENAS tahun 2015 yang dirilis BPS, konsumsi tempe rata-rata per orang per tahun di Indonesia sebesar 6,99 $\mathrm{kg}$ dan tahu 7,51 kg (Riniarsi, 2016).

Kebutuhan kedelai domestik sekitar 2,2 juta ton per tahun dengan proporsi terbesar untuk tempe dan tahu yaitu 1,84 juta ton $(83,7 \%)$, diikuti untuk kecap, tauco, dan produk kedelai lainnya di posisi kedua yaitu 323.400 ton $(14,7 \%)$ (Pusat Data dan Sistem Informasi Pertanian, 2014). Tingkat konsumsi kecap dilaporkan 0,62 kg/kapita/tahun (setara kedelai) dengan laju peningkatan kebutuhan 5,7 \% per tahun (Anonim, 2004 dalam Kristiani, 2013).

Kedelai yang dibudidayakan sebenarnya terdiri dari kedelai putih, yang bijinya bisa berwarna kuning, agak putih, atau hijau dan kedelai hitam (berbiji hitam). Biji kedelai merupakan sumber utama protein nabati dan minyak nabati dunia. Biji kedelai berkulit hitam mengandung banyak anthosianim, dimana anthosianim tinggi mempunyai aktivitas antioksidan besar (Futura et al., 2002).

Untuk mengatasi kekurangan pasokan kedelai maka diperlukan suatu usaha untuk meningkatkan produksi kedelai nasional dan khususnya produksi kedelai yang ada di Sulawesi Selatan. Rendahnya produksi kedelai Indonesia salah satunya dikarenakan belum maksimalnya pengetahuan petani dalam penggunaan teknologi produksi yang mendukung pertanian berkelanjutan dan semakin berkurangnya sumber daya lahan yang subur karena penggunaan pupuk anorganik secara terus menerus.

Salah satu hal yang sangat mempengaruhi produksi kedelai adalah ketersediaan unsur hara yang dibutuhkan tanaman. Banyak cara yang digunakan untuk memenuhi ketersediaan unsur hara dalam tanah. Salah satunya adalah melalui pemberian pupuk organik yang bertujuan untuk meningkatkan bahan organik dalam tanah, memperbaiki sifat kimia dan biologi tanah. Aplikasi pupuk organik dapat langsung kedalam tanah, dan bisa juga diaplikasikan melalui daun.

Di Indonesia jumlah varietas kedelai hitam yang dikembangkan sangat minim. Padahal dari segi syarat tumbuh kedelai hitam (Glycine soja) lebih cocok ditanam di daerah tropis. Salah satu keunggulan dari kedelai hitam adalah mengandung anthosianin lebih banyak dan memiliki daya simpan lebih lama dibanding kedelai kuning. Berkembangnya industri pangan berbahan baku kedelai disertai dengan pertumbuhan penduduk mengakibatkan 
permintaan kedelai di Indonesia menjadi meningkat tajam, namun produksi nasional cenderung menurun sehingga defisit kedelai terus meningkat. Hal ini menyebabkan Indonesia semakin tergantung pada komoditi impor. Banyak sekali manfaat kedelai hitam, seperti bahan makanan sehat atau industri kecap yang berkualitas baik, oleh karena itu perlu adanya peningkatan produksi dan produktivitas kedelai hitam.

Menurut Budiono (2009), bahwa penggunaan pupuk kimia, pestisida, dan bahan kimia lainnya secara terus menerus dapat merusak biota tanah, reistensi hama dan penyakit, serta dapat merubah kandungan vitamin pada beberapa komoditi sayuran dan buah. Hal ini tentunya jika dibiarkan lebih lanjut akan berpengaruh fatal pada kesehatan manusia. Bahkan jika sayuran dan buah yang telah tercemar tersebut dikonsumsi oleh manusia secara terus menerus tentunya akan menyebabkan kerusakan jaringan bahkan kematian.

Penggunaan pupuk anorganik yang tidak disertai dengan pupuk organik akan mengakibatkan kesuburan tanah berkurang, sehingga mengakibatkan kadar bahan organik di dalam tanah sangat rendah yakni kurang dari $2 \%$ dan menjadi faktor pembatas untuk mencapai produksi yang tinggi. Sedangkan untuk mencapai produktivitas optimal dibutuhkan bahan organik >2,5 \% (Hairiah et al., 2000). Oleh karena itu, diperlukan upaya peningkatan produktivitas dalam negeri melalui penambahan bahan organik dan mengurangi penggunaan pupuk anorganik. Penambahan bahan organik ke dalam tanah dapat diperoleh dari berbagai sumber antara lain pupuk hijau, pupuk kandang, sampah hijauan, sampah kota dan pupuk bokashi.

Salah satu upaya yang dapat dilakukan yaitu dengan penambahan bahan organik melalui pemupukan, diantaranya dengan mengunakan bokashi dari bahan organik yang dikomposkan. Bahan organik mengalami berapa kali perombakan dengan mikroorganisme tanah yang menjadi humus bahan organik. Menurut Wiwidana dan Higa (2005), pemberian EM-4 pada proses pembuatan bokashi dapat meningkatkan keragaman dan populasi mikroorganisme, sehingga dapat mempercepat proses penguraian. Lingga dan Marsono (2010), bila bokashi dimasukkan ke dalam tanah, bahan organiknya dapat digunakan sebagai pakan oleh mikroorganisme untuk berkembang biak dalam tanah, sekaligus 
sebagai tambahan persedianan unsur hara bagi tanaman. Bokashi adalah kompos yang dihasilkan melalui fermentasi dengan pemberian Effektive Mikroorganisme-4 (EM-4) yang merupakan salah satu aktifator untuk mempercepat proses pembuatan kompos (Indriani, 2011).

Penggunaan pupuk organik memberikan pengaruh yang besar terhadap sifat fisik, kimia dan biologi tanah. Oleh karena itu pemberian pupuk organik dinilai sangat mendukung upaya peningkatan produktivitas tanaman (Musnamar, 2003). Upaya yang dilakukan untuk menambah peningkatan hasil produksi baik kualitas dan kuantitas produksi kedelai adalah dengan penambahan bahan organik dalam tanah agar dapat menunjang pertumbuhan dan perkembangan akar tanaman yang dapat lebih efektif. Bahan organik berfungsi sebagai pengikat butiran-butiran tanah yang menjadikannya agregat yang mantap (Mulat, 2003).

Pupuk bokashi kotoran sapi merupakan salah satu alternatif dalam penerapan teknologi pertanain organik yang berwawasan lingkungan dan berkelanjutan. Kotoran sapi merupakan bahan organik yang mempunyai prospek yang baik untuk dijadikan pupuk organik, karena mempunyai kandungan unsur hara yang cukup tinggi yaitu $\mathrm{C}$ organik 18,76 $\%, \mathrm{~N} 1,06 \%, \mathrm{P} 0,52 \%, \mathrm{~K} 0,95 \%, \mathrm{Ca}$ 1,06\%, Mg 0,86\%, Na 0,17\%, Fe 5726 ppm, Mn 334 ppm, Zn 122 ppm, Cu 20 ppm, Cr 6 ppm, C/N 17,69\%, Kadar air 24,21\% (Yuliprianto, 2010).

Berdasarkan uraian tersebut di atas maka dilakukan penelitian untuk mengkaji respon pertumbuhan dan produksi 2 varietas kedelai hitam dengan pemberian pupuk organik.

\section{METODE PENELITIAN}

Penelitian ini dilaksanakan di lokasi lahan praktek Politeknik Pembangunan Pertanian (Polbangtan) Gowa, Kelurahan Romanglompoa,

Kecamatan Bontomarannu, Kabupaten Gowa, terletak pada titik koordinat $05^{\circ} 13^{\prime} 57,4^{\prime \prime}$ LS dan 119²9'61,9" BT. Ketinggian 28 mdpl dengan jenis tanah Alfisol. Penelitian ini berlangsung bulan Juli sampai Desember 2018.

Percobaan pertumbuhan dan produksi 2 varietas kedelai hitam (01: Detam-3 dan 02: Detam-4) sebagai petak utama didesain dengan Rancangan Split Plot Design dan sebagai anak petak adalah pemupukan bahan organik yang terdiri 
dari tiga jenis campuran bahan organik ton/ha bokashi daun gamal (bokashi yaitu: P1 : 30 ton/ha bokashi jerami padi kotoran sapi + daun gamal + sekam padi (kotoran sapi + jerami padi + sekam padi dengan perbandingan 3:1:0.5). Dari kedua dengan perbandingan 3:1:0,5), P2 : 30 faktor diperoleh 6 kombinasi perlakuan ton/ha bokashi batang pisang (bokashi dan diulang sebanyak tiga kali sehingga kotoran sapi + batang pisang + sekam padi diperoleh 18 unit satuan percobaan. dengan perbandingan $3: 1: 0,5)$, dan $\mathrm{P} 3: 30$

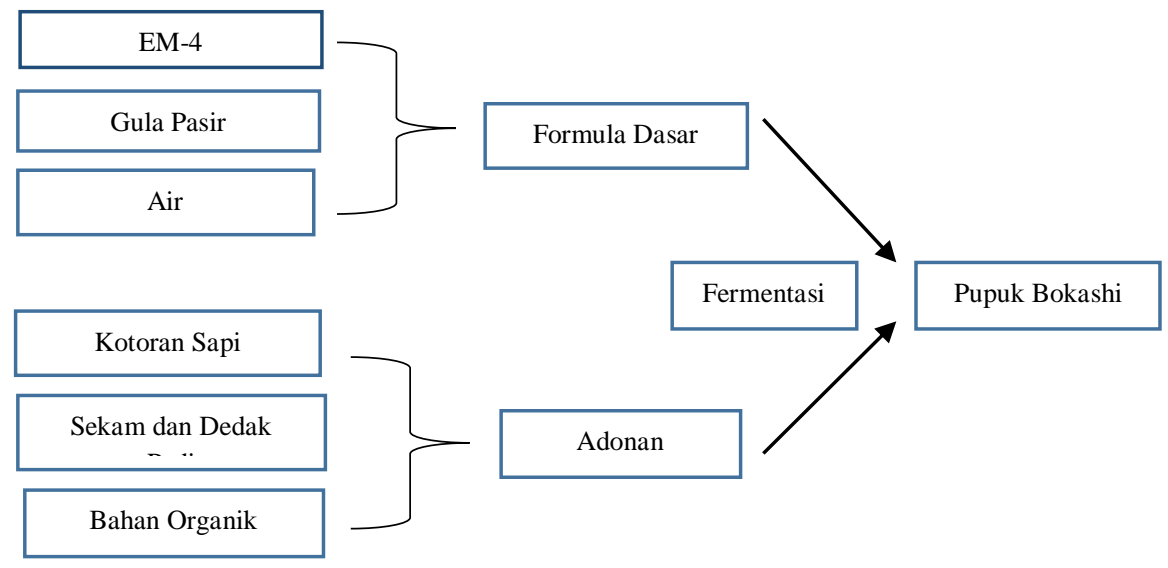

Gambar 1 Proses Pembuatan Pupuk Bokashi

Ada 2 parameter utama yang digunakan, polong, bobot 100 butir biji, bobot biji per parameter tanaman dan parameter tanah. petak dan produksi per hektar..

Parameter tanaman da tanah terdiri dari:

2. Parameter tanah yang digunakan adalah 1a. Tinggi tanaman dan jumlah daun yang $\mathrm{N}$ total (Kjeldahl). $\mathrm{pH}\left(\mathrm{H}_{2} \mathrm{O} \& \mathrm{KCl}\right.$ dilakukan setiap dua minggu. dengan $\mathrm{pH}$ meter). KTK $\left(\mathrm{NH}_{4} \mathrm{OAc} 1 \mathrm{~N}\right.$ Pengamatan dilakukan terhadap 12 pH7). C-organik (Walkey \& Black) tanaman contoh untuk setiap kombinasi dilakukan pada awal dan akhir percobaan perlakuan. Pengamatan terhadap waktu keluarnya bunga $50 \%$, pembentukan polong dan waktu panen.

1b. Jumlah polong, persentase polong berisi, persentase polong hampa, bobot

\section{Analisis Data}

Data hasil pengamatan yang diperolah dianalisis secara statistik (Analisis ragam dengan uji F) sesuai dengan rancangan yang digunakan. Pada penelitian ini percobaan dianalisis dengan 
menggunakan Rancangan Split Plot $\epsilon_{\mathrm{ijk}}$ : pengaruh acak a

Design (Sastrosupadi, 1999) dengan $\epsilon b_{\mathrm{ijk}} \quad$ : pengaruh acak b

model matematik sebagai berikut :

Sidik ragam yang menunjukkan $\mathrm{F}$

$\mathrm{Y}_{\mathrm{ijk} 1}: \mu+\beta_{\mathrm{i}}+\mathrm{Aj}+\mathrm{Ca}_{\mathrm{ijk}}+\mathrm{Bk}+(\mathrm{AB})_{\mathrm{jk}}+$ hitung nyata atau sangat nyata maka

$\mathrm{Eb}_{\mathrm{ijk}}$

$\mathrm{I}=1 ; 2 ; 3$

$\mathrm{J}=1 ; 2 ; 3 ; 4$

$\mathrm{K}=1 ; 2$

Dimana :

$\mathrm{Y}_{\mathrm{ijk} \mathrm{l}} \quad$ : nilai hasil pengamatan dari

pengaruh perlakuan faktor A taraf

ke-i.

faktor B tarak ke-j dan faktor C

taraf ke-k pada ualangan ke-i.

$\mu \quad$ : nilai tengan umum.

$\beta_{\mathrm{i}} \quad$ : pengaruh blok atau ualangan ke-i.

$\mathrm{A}_{\mathrm{j}} \quad$ : pengaruh petak utama (A) taraf ke-j

$\mathrm{B}_{\mathrm{k}} \quad$ : pengaruh anak petak (B) taraf ke$\mathrm{k}$

$\mathrm{AB}_{\mathrm{jk}}$ : pegaruh interaksi petak utama analisis data dilanjutkan pengujiannya dengan menggunakan uji Beda Nyata Terkecil (BNT) (Steel and Torrie. 1981).

\section{HASIL DAN PEMBAHASAN}

\section{Pertumbuhan Tanaman}

\section{Tinggi Tanaman}

Berdasarkan analisis sidik ragam perlakuan bahan organik memberikan pengaruh tidak nyata sedangkan perlakuan varietas memberikan pengaruh yang nyata terhadap tinggi tanaman, namun tidak terdapat interaksi antara perlakuan varietas dan pemberian bahan organik. Rata-rata tinggi tanaman dapat dilihat pada Gambar 2.

(A) dan faktor B (II)

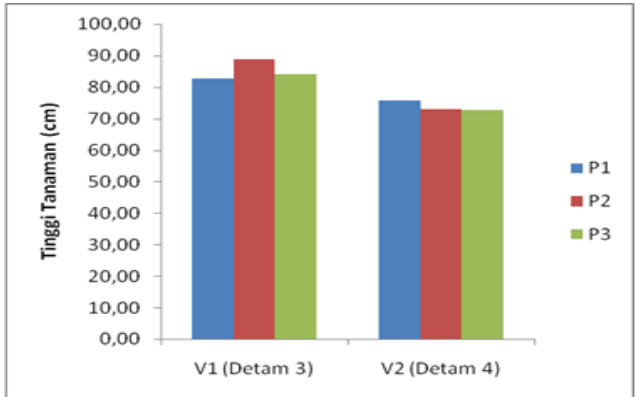

Gambar 2 Tinggi Tanaman Perlakuan P1, P2 dan P3 
Gambar 2 di atas menunjukkan bahwa varietas Detam-3 menunjukkan tanaman yang lebih tinggi dibandingkan varietas Detam-4. Berdasarkan uji BNT pada taraf 5\%, varietas Detam-3 (V1) menunjukkan tanpa pengaruh berbeda terhadap varietas Detam-4 (V2). Jika ditinjau dari perlakuan pupuk organik dapat dilihat bahwa pupuk organik dengan campuran bokashi kotoran sapi, batang pisang, dan sekam padi (P2) menunjukkan tanaman tertinggi. Dilihat dari hasil kombinasi perlakuan, varietas
Detam-3 dengan pemberian pupuk organik campuran batang pisang memberikan pengaruh terbaik. Menurut Sugiarti (2011), kompos batang pisang mampu menyuplai hara dan mampu memperbaiki struktur tanah yang sama dengan pupuk organik yang berasal dari kotoran hewan. Kandungan Nitrogen yang tinggi akan memacu pertumbuhan ujung tanaman sedangkan $\mathrm{N}$ yang terbatas akan memacu pertumbuhan akar (Sari et al., 2014).

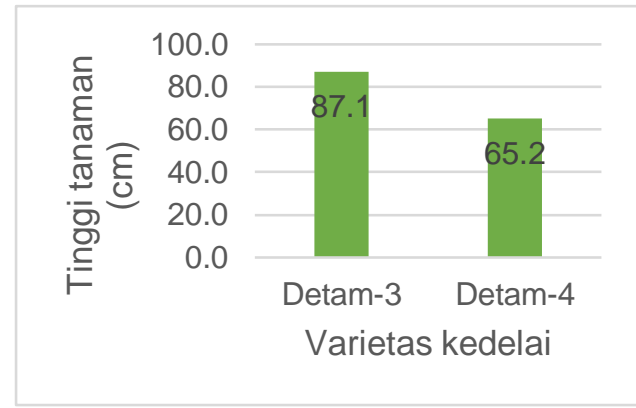

Gambar 3 Tinggi Tanaman Perlakuan Kontrol (P0)

Terdapat perbedaan tinggi tanaman antara varietas Detam-3 dan Detam-4 meskipun keduanya tidak diberikan perlakuan (kontrol). Adanya perbedaan tersebut disebabkan oleh adanya perbedaan sifat atau keunggulan dari masing-masing varietas sesuai dengan genotipe yang dimilikinya. Sesuai dengan Sitompul dan Guritno (1995) yang menyatakan bahwa perbedaan susunan genetik merupakan salah satu penyebab keragaman penampilan tanaman. Program genetik akan diekspresikan pada suatu fase pertumbuhan yang berpengaruh dapat diekspresikan pada berbagai sifat tanaman yang mencakup bentuk dan fungsi tanaman yang menghasilkan keragaman pertumbuhan tanaman.

\section{Jumlah Daun}

Berdasarkan analisis sidik ragam perlakuan bahan organik memberikan 
pengaruh tidak nyata sedangkan perlakuan varietas dan pemberian bahan organik. varietas memberikan pengaruh yang nyata Rata-rata jumlah daun dapat dilihat pada terhadap jumlah daun, namun tidak Tabel 1.

terdapat interaksi antara perlakuan

Tabel 1 Rata-Rata Jumlah Daun Varietas Detam-3 dan Detam-4 Dengan Perlakuan Pupuk Organik

\begin{tabular}{cccccc}
\hline \hline \multirow{2}{*}{ Varietas } & \multicolumn{3}{c}{ Pupuk organik } & Rata-rata & $\begin{array}{c}\text { NPBNT } \\
0,05\end{array}$ \\
\cline { 2 - 4 } & $\begin{array}{c}\text { Jerami padi } \\
(\mathrm{P} 1)\end{array}$ & $\begin{array}{c}\text { Batang pisang } \\
(\mathrm{P} 2)\end{array}$ & $\begin{array}{c}\text { Daun } \\
\text { gamal (P3) }\end{array}$ & & 5,05 \\
\hline \hline Detam-3 (V1) & 54,40 & 50,87 & 46,17 & $50,48^{\mathrm{a}}$ & 1,05 \\
Detam-4 (V2) & 40,57 & 39,27 & 39,40 & $39,74^{\mathrm{b}}$ & \\
\hline \hline Rata-rata & 47,48 & 45,07 & 42,78 & & \\
\hline \hline
\end{tabular}

Keterangan: Angka-angka yang diikuti oleh huruf yang sama $(\mathrm{a}, \mathrm{b})$ berarti tidak berbeda nyata pada uji taraf BNT 5\%

Tabel 1 di atas menunjukkan bahwa pupuk organik dapat dilihat bahwa pupuk varietas Detam-3 menunjukkan tanaman organik dengan campuran bokashi kotoran dengan jumlah daun lebih banyak sapi, jerami padi, dan sekam padi (P1) dibandingkan varietas Detam-4. menunjukkan jumlah daun terbanyak. Berdasarkan uji BNT pada taraf 5\%, Dilihat dari hasil kombinasi perlakuan, varietas Detam-3 (V1) menunjukkan varietas Detam-3 dengan pemberian pengaruh berbeda terhadap varietas pupuk organik campuran jerami padi Detam-4 (V2). Jika ditinjau dari perlakuan memberikan pengaruh terbaik.

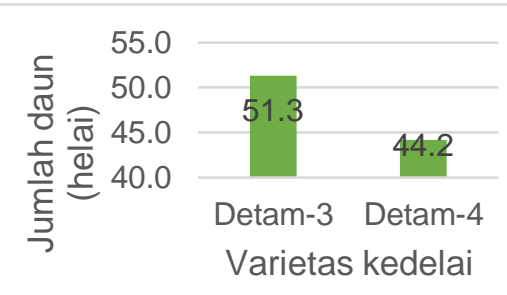

Gambar 4 Jumlah Daun Perlakuan Kontrol (P0)

Terdapat perbedaan yang besar dari berpengatuh satu sama lain sehingga akan masing-masing varietas terhadap menunjukkan keragaman penampulan. parameter yang diamati. Hal ini terjadi Menurut Lovelles (1989) suatu fenotip karena adanya perbedaan genetik pada individu merupakan hasil interaksi antara kedua varietas tanaman. Setiap varietas genotip dan lingkungannya. memiliki ciri dan sifat khusus yang 
2. Pengaruh Perlakuan Terhadap Sifat tanah. Kedua parameter ini penting untuk

\section{Kimia Tanah}

\section{Kemasaman Tanah}

Kemasaman tanah yang dianalisis terdiri atas $\mathrm{pH}_{2} \mathrm{O}$ dan $\mathrm{pH} \mathrm{KCl}$. Hal ini bertujuan untuk mengestimasi jumlah domianan antara kation dan anion dalam dianalisis utamanya pada tanah tropis. Estimasi tersebut didasarkan atas selisih $\mathrm{pH} \mathrm{KCl}$ dan $\mathrm{pH} \mathrm{H} 2 \mathrm{O}$ (Mekaru dan Uehara, 1972). Pengaruh perlakuan terhadap $\mathrm{pH}$ tanah dapat dilihat pada tabel 2 dan tabel 3.

Tabel 2 pH Tanah $\left(\mathrm{H}_{2} \mathrm{O}\right)$ Pada Kombinasi Perlakuan Varietas Kedelai dan Pupuk Organik

\begin{tabular}{ccccc}
\hline \hline \multirow{2}{*}{ Varietas } & \multicolumn{3}{c}{ Pupuk organik } & \multirow{2}{*}{ Kontrol } \\
\cline { 2 - 4 } & Jerami padi (P1) & Batang pisang (P2) & Daun gamal (P3) & \\
\hline \hline Detam-3 (V1) & 6,3 & 6,3 & 6,4 & \multirow{2}{*}{6,3} \\
Detam-4 (V2) & 6,3 & 6,5 & 6,6 & \\
\hline \hline
\end{tabular}

Berdasarkan tabel ini di atas, adalah perlakuan dengan dosis 6 ton/ha keseluruhan perlakuan memberikan menunjukkan peningkatan $\mathrm{pH}$ tanah pengaruh yang tidak signifikan, tertinggi yaitu dari 5,04 menjadi 6,35. ditunjukkan dari rata-rata selisih antar Perlakuan kompos dari daun gamal perlakuan hanya 0,1-0,3 bahkan ada yang memberikan pengaruh terbaik terhadap menunjukkan kesamaan nilai. Perlakuan $\mathrm{pH}$ tanah. Hal ini terjadi karena daun gamal pada varietas Detam-4 (V2P3) berdasarkan hasil analisis pupuk, menunjukkan nilai $\mathrm{pH}$ tertinggi, yaitu 6,6. dibandingkan kompos dari jerami padi Hal ini sesuai dengan penelitian Putro dan kompos dari batang pisang, kompos (2016) bahwa pemberian pupuk hijau dari daun gamal memiliki pH pupuk paling daun gamal dapat meningkatkan $\mathrm{pH}$ tanah tinggi, yaitu 5,74 sehingga memungkinkan seiring denga penambahan dosis pupuk berkurangnya donor $\mathrm{H}^{+}$dan meningkatnya hijau daun gamal. Hasil penelitian tersebut $\mathrm{OH}^{-}$.

Tabel 3 pH Tanah (KCl) Pada Kombinasi Perlakuan Varietas Kedelai dan Pupuk Organik

\begin{tabular}{ccccc}
\hline \hline \multirow{2}{*}{ Varietas } & \multicolumn{3}{c}{ Pupuk organik } & Kontrol \\
\cline { 2 - 5 } & Jerami padi (P1) & Batang pisang (P2) & Daun gamal (P3) & \multirow{2}{*}{5,0} \\
\hline \hline Detam-3 (V1) & 5,0 & 4,8 & 5,0 & 5,6 \\
Detam-4 (V2) & 5,3 & 3,2 & 5,6 & \\
\hline \hline
\end{tabular}


Tabel 3 menunjukkan pengaruh perlakuan terhadap $\mathrm{pH} \mathrm{KCl}$. Berdasarkan tabel di atas, sama halnya dengan data pada $\mathrm{pH} \mathrm{H} 2 \mathrm{O}$, Perlakuan daun gamal pada varietas Detam-4 (V2P3) menunjukkan nilai $\mathrm{pH}$ tertinggi, yaitu 5,6. Namun yang terendah ditunjukkan oleh V2P2. Terdapat hasil yang sejalan antara hasil $\mathrm{pH} \mathrm{H}_{2} \mathrm{O}$ dan $\mathrm{pH} \mathrm{KCl,} \mathrm{hal} \mathrm{ini} \mathrm{terjadi} \mathrm{sebab} \mathrm{analisis}$ $\mathrm{pH}$ tanah tetap berdasarkan pada jumlah ion Hidrogen dalam larutan tanah sehingga jika larutan yang digunakan dalam analisis diganti menjadi $\mathrm{KCl}$ maka hasilnya akan tetap berkorelasi positif. Jika dilihat dari selisih antara $\mathrm{pH}_{2} \mathrm{O}$ dan $\mathrm{pH} \mathrm{KCl}$, jumlah anion mendominasi reaksi dalam tanah. Berdasarkan penelitian Zulkarnain et al. (2013), aplikasi bahan organik dapat meningkatkan hasil pertumbuhan tanaman dan memperbaiki kualitas tanah. Efek paling baik terjadi pada perlakuan pupuk kandang dengan dosis 60 ton/ha sampai 100 ton/ha, yaitu menunjukkan hasil berupa peningkatan $\mathrm{pH}$ tanah.

\section{C-Organik Tanah}

C-organik merupakan parameter yang penting sebab menunjukkan persentase Corganik dalam tanah yang akan menunjukkan pengaruh perlakuan terhadap perubahan C-organik dalam tanah. Tabel 4 menunjukkan pengaruh perlakuan terhadap persentase C-organik tanah.

Tabel 4 C-Organik Tanah Pada Kombinasi Perlakuan Varietas Kedelai dan Pupuk Organik

\begin{tabular}{ccccc}
\hline \multirow{2}{*}{ Varietas } & \multicolumn{3}{c}{ Kontrol } \\
\cline { 2 - 5 } & Jerami padi (P1) & Batang pisang (P2) & Daun gamal (P3) & \\
\hline \hline Detam-3 (V1) & 1,90 & 1,99 & 2,11 & 1,48 \\
Detam-4 (V2) & 1,55 & 1,63 & 1,69 & \\
\hline \hline
\end{tabular}

Tabel di atas menunjukkan bahwa kandungan C-organik sebesar 2\%-3\%. Hal perlakuan V1P3 memberikan nilai C- ini dilihat dari data di atas bahwa terdapat organik tanah tertinggi, yaitu 2,1. peningkatan C-organik sebelum dan Berdasarkan Balai Penelitian Tanah sesudah perlakuan. Penelitian Calcino et (2009), persentase ini tergolong sedang. al. (2009) menunjukkan aplikasi kompos Sejalan dengan hasil penelitian Putro pada lahan tebu selama tiga tahun (2016) mengenai pengaruh pupuk hijau meningkatkan hasil tebu dan hasil gula dari daun gamal terhadap kandungan C- secara signifikan dibandingkan dengan organik tanah, yaitu terjadi peningkatan 
kontrol. Aplikasi kompos juga Dengan penambahan pupuk organik meningkatkan kandungan C-organik. diharapkan dapat meningkatkan unsur

\section{Nitrogen (N) Total}

Nitrogen merupakan salah satu unsur hara makro yang dibutuhkan tanaman. Namun sayangnya bersifat paling mobile diantara unsur hara makro lainnya. hara $\mathrm{N}$ dalam tanah. Secara umum dapat disebutkan bahwa setiap ton pupuk kandang mengandung $5 \mathrm{~kg} \mathrm{~N}, 3 \mathrm{~kg} \mathrm{P}_{2} \mathrm{O} 5$, dan $5 \quad \mathrm{~kg} \quad \mathrm{~K}_{2} \mathrm{O}$ serta unsur-unsur hara esensial lain dalam jumlah yang relatif kecil (Knuti et al., 1970).

Tabel 5 N Total Tanah Pada Kombinasi Perlakuan Varietas Kedelai dan Pupuk Organik

\begin{tabular}{ccccc}
\hline \hline \multirow{2}{*}{ Varietas } & \multicolumn{3}{c}{ Kontrol } \\
\cline { 2 - 5 } & Jerami padi (P1) & Batang pisang (P2) & Daun gamal (P3) & \\
\hline \hline Detam-3 (V1) & 0,22 & 0,17 & 0,17 & 0,17 \\
Detam-4 (V2) & 0,11 & 0,11 & 0,33 & \\
\hline \hline
\end{tabular}

Tabel 5 menunjukkan pengaruh perlakuan terhadap $\mathrm{N}$ total dalam tanah. Pada tabel di atas terlihat bahwa perlakuan V2P3 menunjukkan nilai $\mathrm{N}$ total tertinggi. Perlakuan terhadap daun gamal sebelum fermentasi berpengaruh nyata terhadap kandungan $\mathrm{N}, \mathrm{K}, \mathrm{Mg}$, dan $\mathrm{pH}$. Dengan pemanfaatan daun gamal dapat diperoleh sebesar 3,15\% N, 0,22 \% P, 2,65\% K, 1,35\% Ca dan 0,41\% Mg (Ibrahim, 2002).

\section{Kapasitas Tukar Kation (KTK)}

KTK merupakan sifat kimia tanah yang menunjukkan kemampuan pertukaran kation basa dalam tanah di mana semakin tinggi nilai pertukaran ini maka ketersediaan basa-basa dalam tanah akan semakin tinggi sehingga dapat dimanfaatkan untuk pertumbuhan tanaman. Lebih lanjut sifat kimia tanah diperbaiki dengan meningkatnya Kapasitas Tukar Kation (KTK) dan ketersediaan hara.

Tabel 6 KTK Tanah Pada Kombinasi Perlakuan Varietas Kedelai dan Pupuk Organik

\begin{tabular}{ccccc}
\hline \hline \multirow{2}{*}{ Varietas } & \multicolumn{3}{c}{ Pupuk organik } & Kontrol \\
\cline { 2 - 5 } & Jerami padi (P1) & Batang pisang (P2) & Daun gamal (P3) & \multirow{2}{*}{21,96} \\
\hline \hline Detam-3 (V1) & 24,25 & 26,52 & 24,98 & 2,84 \\
Detam-4 (V2) & 26,45 & 25,32 & 23,84 & \\
\hline \hline
\end{tabular}


Tabel 6 menunjukkan nilai KTK tanah berdasarkan perlakuan yang diberikan. Perlakuan V1P2 menunjukkan KTK tanah tertinggi, yaitu 26,5 dan yang terendah adalah V2P3. Berdasarkan penelitian Kusumawati (2015) yang mengkarakterisasi pupuk berbahan batang pisang, nilai $\left(\mathrm{N}+\mathrm{P}_{2} \mathrm{O}_{5}+\mathrm{K}_{2} \mathrm{O}\right)$ kompos berbahan batang pisang adalah 7,74\% Nilai ini sesuai dengan syarat teknis minimal pupuk Organik Padat Permentan Nomor $\quad 70 / P e r m e n t a n / S R .140 / 10 / 2011$ yang mensyaratkan nilai $\left(\mathrm{N}+\mathrm{P}_{2} \mathrm{O}_{5}+\mathrm{K}_{2} \mathrm{O}\right)$ minimal 4\%. Hal ini menunjukkan bahwa kompos berbahan batang pisang dapat dijadikan sumber hara jika diaplikasikan ke lahan, karena memiliki nilai hara makro $\left(\mathrm{N}+\mathrm{P}_{2} \mathrm{O}_{5}+\mathrm{K}_{2} \mathrm{O}\right)$ yang besar. Tingginya kandungan unsur-unsur kation basa tersebut memungkinkan KTK tanah dengan perlakuan batang pisang pun dapat memberikan hasil terbaik. Lebih lanjut hasil yang didapatkan adalah bahwa pupuk kompos berbahan batang pisang memiliki nilai C-organik 29,7\% yang sesuai dengan standar syarat teknis minimal pupuk Organik Padat Permentan Nomor 70/Permentan/SR.140/10/2011 yaitu minimal 15\%. Dengan tingginya kandungan C-organik tersebut maka memungkinkan adanya peningkatan KTK tanah.

\section{KESIMPULAN DAN SARAN}

\section{Kesimpulan}

Berdasarkan hasil penelitian dapat disimpulkan sebagai berikut:

1.Kedelai hitam Varietas Detam-3 memperlihatkan pertumbuhan dan produksi yang lebih baik dibandingkan dengan varietas Detam-4.

2.Pupuk organik dengan campuran bokashi kotoran sapi, jerami padi, dan sekam padi menunjukkan pengaruh terbaik terhadap pertumbuhan dan produksi tanaman kedelai hitam.

3.Tidak terdapat interaksi antara jenis pupuk organik dan varietas kedelai terhadap pertumbuhan dan produksi kedelai hitam.

\section{Saran}

Berdasarkan kesimpulan di atas maka disarankan untuk penggunaan varietas kedelai hitam Detam-3 yang disertai dengan penggunaan pupuk organik bokashi berbahan dasar jerami padi sebagai bagian dari sistem pertanian zero waste untuk menunjang produksi yang optimum. 


\section{DAFTAR PUSTAKA}

Balai Penelitian Tanah. 2009. Petunjuk Teknis Analisis Kimia Tanah, Tanaman, Air, dan Pupuk. Bogor: Badan Penelitian dan Pengembangan Pertanian, Departemen Pertanian.

Budiono, R. 2009. Pengaruh Pemberian Pupuk Organik dan $N$ Terhadap Pertumbuhan dan Hasil Tanaman Jagung Jawa Timur. Balai pengkajian Teknologi Pertanian Jawa Timur. Malang.

Calvino, A. Cirilio, Andrade, Barbieri. 2009. Yield Respons to Narrow Rows Depend on Increased Radiation Interseption. Agron. J .94 : 975-980.

Futura, D.L. and R.E. Mullen. 2002. Influence of Stress During Soybean Black Seed Fill on Seed Weight, Germination, and Seeding Growth Rate. Can J. Plant Sci., 71 : 373-383.

Hairiah K. et all. Pengenalan tanah masam secara bilangan: Refleksi Pengalaman dari Lampung Utara. Word Agroforestry Center. Bogor.

Ibrahim, B. 2002. Intergrasi Jenis Tanaman Pohon Leguminosae dalam Sistem Budidaya Pangan Lahan Kering dan Pengaruhnya Terhadap Sifat Tanah, Erosi, dan Produktifitas Lahan [disertasi]. Makassar : Universitas Hasanuddin.

Indriani, Y. H. 2011. Membuat Kompos Secara Kilat. Penebar Swadaya. Jakarta.

Knuti,L,L,M .Korpi, dan J .C .Hide,1970 . Profitable Soil Management. Prentice Hall . Inc . Englewood Cliffs .N.J.

Kristiani, H. 2013. Pengaruh diferensiasi produk terhadap loyalitas pelanggan [skripsi]. Universitas Pendidikan. Bandung.

Lingga dan Marsono. 2010. Petunjuk penggunaan pupuk. Penerbit Penebar Swadaya, Jakarta.
Loveless, A. R. 1989. Prinsip-Prinsip Biologi Tumbuhan untuk Daerah Tropik 2. Jakarta : PT. Gramedia.

Mekaru, T. dan Uehara, G. 1972. Anion Adsoption in Ferruginous Tropical Soils. Soils Science American Proceeding, Madison, 36(2):296-300.

Mulat, T. 2003. Membuat dan Manfaat Kascing Pupuk Organik Berkualitas. Agromedia Pustaka. Jakarta.

Musnamar, E.I. 2003. Pupuk Organik Padat. Penebar Swadaya. Jakarta.

Putro, Y.D.W. 2016. Pengaruh Dosis Pupuk Hijau Daun Gamal (Gliricidia sepium) terhadap Pertumbuhan dan Hasil Tanaman Buncis (Phaseolus vulgaris L.) [skripsi]. Universitas Kristen Satya Wacana. Salatiga.

Riniarsi T. D., 2016. Kedelai, Outlook Komoditas Pertanian Sub Sektor Tanaman Pangan. Pusat Data dan Sistem Informasi Pertanian. Kementerian Pertanian. Jakarta.

Sari, D.K., Y. Hasana., dan T. Simanungkalit. 2014. Respons Pertumbuhan dan Produksi Beberapa Varietas Kedelai (Glycine max L. (merill)) dengan Pemberian Pupuk Organik Cair. Jurnal Online Agroekoteknologi, 2(2): 653-661. Medan : Universitas Sumatera Utara.

Sastrosupadi. 1999. Rancangan Percobaan Bidang Pertanian, Andalas Press, Padang.

Sitompul, S. M, dan B. Guritno. 1995. Analisis Pertumbuhan Tanaman.Universitas Gadjah Mada. Yogyakarta.

Steel. R. G. D. And J. H. Torrie. 1981. Principles and procedure of Statistics. A Biometrical Approach. Mc Graw Hill International Book Company. New York. 748p.

Sugiarti, H. 2011. Pengaruh Pemberian Kompos Batang Pisang Terhadap Pertumbuhan Semai Jabon [skripsi]. 
Bogor : Institut Pertanian Yulipriyanto, H., 2010. Biologi Tanah dan Bogor.Suharno. (1979). Komposisi Strategi Pengelolaannya. Graha Ilmu. Kimia Sekam Padi, di dalam: Sigit Yogyakarta.

Nugraha dan JettySetiawati, 2001, Zulkarnain, M., B. Prasetya, dan Peluang Agribisnis Arang Sekam, Soemarno. 2013. Pengaruh Kompos, Badan Penelitian Pascapanen Pupuk Kandang, dan Custom-Bio Pertanian, Jakarta

Widiana dan Higa. 2005. Memperpanjang Umur Produktif Jagung Manis. Penebar Swadaya. Jakarta. terhadap Sifat Tanah, Pertumbuhan dan Hasil Tebu (Saccharum officinarum L.) pada Entisol di Kebun Ngrangkah-Pawon, Kediri). Indonesian Green Technology Journal, 2(1) : 45-52. 